\title{
Pyogenic granuloma-like Kaposi sarcoma: A case report with dermatoscopical and histopathological characteristics
}

\author{
Piyojenik granülom benzeri Kaposi sarkomu: Dermatoskopik ve histopatolojik \\ özellikleri ile birlikte olgu sunumu
}

\section{Hatice Gamze Demirdağ, ๑ Emine Benzer*, ๑ Burcu Tuğrul**}

Private Clinic, Department of Dermatology, Ankara, Turkey *University of Health Sciences Turkey, Ankara Oncology Training and Research Hospital, Clinic of Pathology; **Department of Dermatology,

Ankara, Turkey

\begin{abstract}
Pyogenic granuloma-like Kaposi sarcoma (PG-like KS) is an uncommon clinicopathologic variant of KS. This is a challenging entity to diagnose because it combines the clinical and histopathological characteristics of both PG and KS. Herein, we present a case of PG-like nodular-type KS with dermatoscopical and histopathological characteristics.

Keywords: Kaposi sarcoma, pyogenic granuloma, PG-like KS, solitary nodule, dermoscopy, dermatoscopy, histopathology
\end{abstract}

Öz

Piyojenik granülom benzeri Kaposi sarkomu (PG-benzeri KS), KS'nin nadir bir klinikopatolojik türüdür. Hem PG hem de KS'nin klinik ve histopatolojik özelliklerini içermekte ve tanı konması zor olabilmektedir. Bu çalışmada, soliter nodülü olup PG-benzeri KS nodüler tip tanısı konan bir olgu, dermatoskopik ve histopatolojik özellikleri ile beraber sunulmakta ve tartısıılmaktadır.

Anahtar Kelimeler: Kaposi sarkomu, piyojenik granülom, PG benzeri KS, soliter nodül, dermoskopi, dermatoskopi, histopatoloji

\section{Introduction}

Kaposi sarcoma (KS) is a vascular tumor characterized by spindle cell and endothelial cell proliferation'. Lesions begin as macules and progress to plaques and nodules². Moreover, KS is characterized by multiple lesions on the distal lower extremities ${ }^{2}$. Solitary nodule presentations are uncommon. Pyogenic granuloma-like KS (PG-like KS) is a rare clinicopathologic variant of KS and a challenging entity that can exhibit clinical and histologic characteristics of both PG and KS ${ }^{3-7}$. There have been some reports of PG-like KS, but cases with only a solitary nodule and no history of KS have been reported infrequently ${ }^{7}$. Herein, we present a case of a solitary nodule diagnosed as PG-like nodular-type $\mathrm{KS}$ and discuss its dermatoscopical and histopathological characteristics.

Address for Correspondence/Yazışma Adresi: Hatice Gamze Demirdağ MD, Private Clinic, Department of Dermatology, Ankara, Turkey Phone: +90 3123360909 E-mail: demirdaggamze@gmail.com Received/Geliş Tarihi: 17.12.2020 Accepted/Kabul Tarihi: 17.03.2021 ORCID: orcid.org/0000-0001-9484-2054

Cite this article as: Demirdağ HG, Benzer E, Tuğrul B. Pyogenic granuloma-like Kaposi sarcoma: A case report with dermatoscopical and histopathological characteristics. Turkderm-Turk Arch Dermatol Venereol 2021;55:147-9. 


\section{Case Report}

An 85-year-old woman was admitted to our clinic with a non-healing reddish nodule on her left wrist dorsum that had grown gradually in size over the course of 6 months. Further, physical examination showed a well-defined, indurated, reddish ulcerated nodule measuring $1 \times 1.5$ $\mathrm{cm}$ in diameter (Figure 1a). She had no prior history of KS and was not immunosuppressed. She had no more lesions in the rest of her skin. Dermatoscopic examination revealed red-yellow structureless areas, ulceration, fiber sign, white collarette sign, and linear irregular vessels (Figure 1b). Lesion was totally excised, and histopathology revealed polypoid neoplastic tissue with nodular/lobular pattern under ulcerated stratified squamous epithelium containing capillary vascular structures, extravasated erythrocytes, and spindle mesenchymal cells forming fascicles and exhibiting mitotic activity (Figure 2). Histochemically, Periodic acid-Schiff-positive eosinophilic globules were discovered. Immunohistochemistry for human herpesvirus-8 (HHV8) and CD34 was positive in these mesenchymal cells, and smooth muscle actin (SMA) and factor VIII (FVIII) antibodies were also positive in vascular structures (Figure 3). Ki67 mitotic activity was 40\% in CD34 (+) neoplastic cells. Based on the clinicopathologic correlation and supportive immunohistochemistry, the diagnosis of PG-like nodular-type KS was confirmed. Informed consent was obtained.

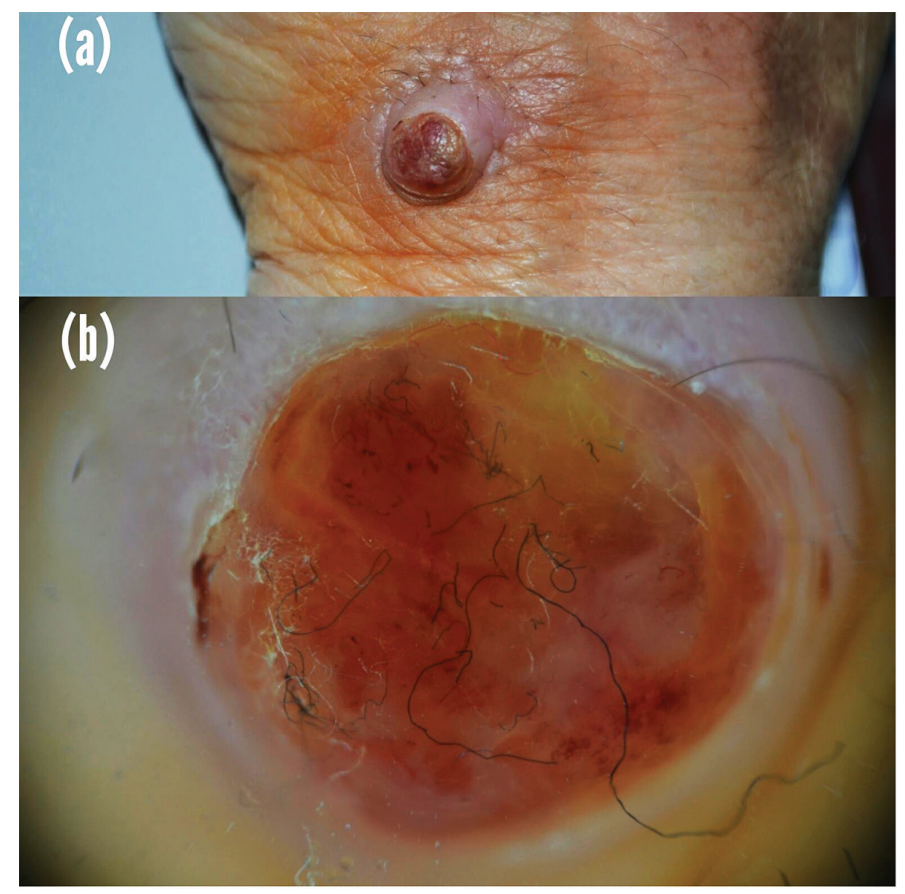

Figure 1. a) A well-defined, indurated, reddish ulcerated nodule measuring $1 \times 1.5 \mathrm{~cm}$ in diameter on the patient's left wrist dorsum. b) Red-yellow structureless areas, ulceration, fiber sign, white collarette sign, and linear irregular vessels on dermatoscopic examination

\section{Discussion}

Clinically, the differential diagnosis of a solitary pink to red nodule includes various inflammatory, benign, and malignant skin conditions. Dermatoscopy is a non-invasive useful tool that provides diagnostic information. The most common dermatoscopical patterns in $\mathrm{KS}$ were found to be bluish-reddish coloration, the rainbow pattern, and a scaly surface ${ }^{1,2}$. The dermatoscopical characteristics of the present case included a red structureless area, a collarette sign, and ulceration, which suggested a possible diagnosis of PG. The most commonly reported dermatoscopical findings for PG were reddish structureless (homogeneous) areas, collarette sign, white intersecting lines, ulceration, hemorrhagic crusts, and blood spots ${ }^{8-10}$. The red structureless area reflects multiple small capillaries and proliferative vessels in the dermis and is not a specific clue for vascular tumors ${ }^{10}$. Furthermore, the collarette sign is a ring-shaped or arcuate squamous structure that is usually located at the periphery of the lesions ${ }^{9}$. It has been observed in patients with PG, clear cell acanthoma, amelanotic melanoma, basal cell carcinoma, angiokeratoma, Spitz nevus, and eccrine poroma ${ }^{9}$. Although this sign has only been reported in a few cases of KS, Ertürk Yılmaz et al. ${ }^{2}$ found it in two-thirds of the KS nodular

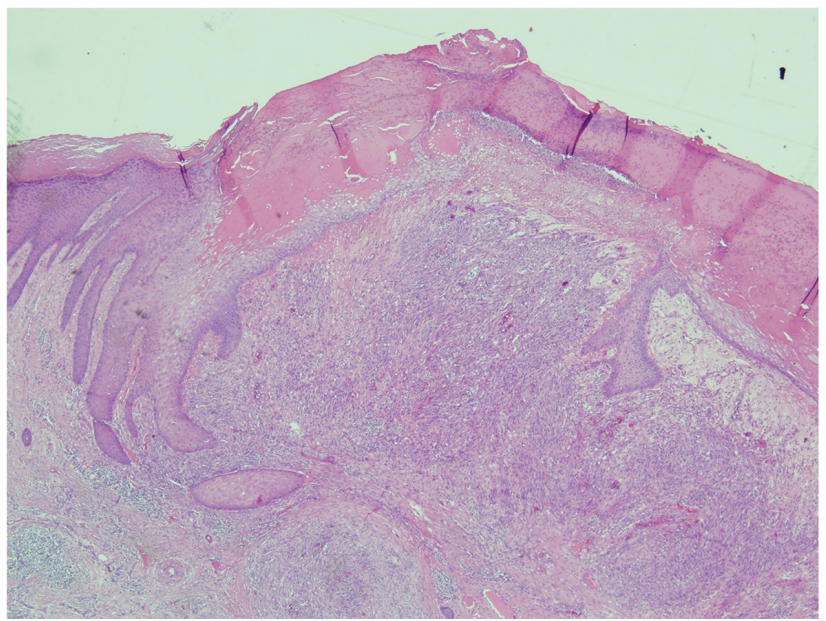

Figure 2. Tumoral tissue consisting of spindle cells with a nodular pattern (hematoxylin and eosin, x40)

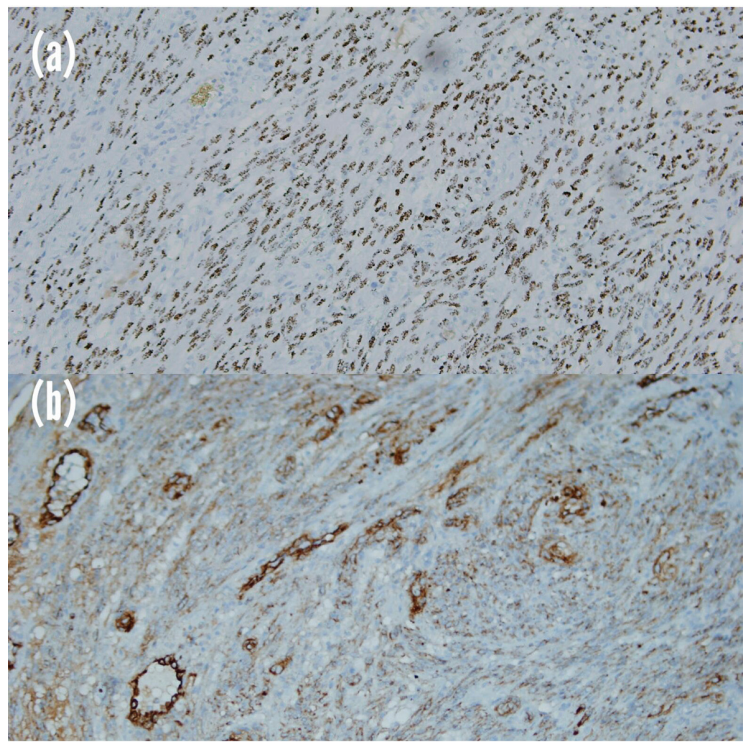

Figure 3. a) Immunohistochemical staining showing HHV-8 nuclear positivity (x200). b) Immunohistochemical staining showing factor VIII positivity in tumoral vascular structures (x200)

HHV: Human herpesvirus-8 
lesions. Ulceration is a very rare characteristic in KS. In another study, none of the KS lesions had ulceration or crusts ${ }^{8}$.

It is extremely difficult to distinguish PG-like KS from PG based solely on clinical and dermatoscopical findings. Hence, histopathological examinations, including HHV-8 staining, are necessary to differentiate them ${ }^{3,6,7}$. Endothelial markers, such as CD31 and CD34, stain spindle cells of nodular KS lesions and can useful as we $\|^{4,5}$. In addition, antibodies to SMA and FVIII, which are commonly found in PG pericytes and mature endothelial cells, can also be used to distinguish. The spindle cells in KS do not express FVIII and SMA due to the absence of both mature endothelial cells and pericytes. However, simultaneous expression of both PG and KS markers may occur ${ }^{5}$. Histomorphologically, although the diagnosis of PG was initially thought with polypoid and lobular pattern in our case, nodular-type KS was considered due to spindle mesenchymal cell bundles containing mitosis. It also demonstrated expression of SMA, FVIII, and CD34, all of which are PG and KS markers. The diffuse nuclear staining with HHV-8 confirmed the diagnosis.

The prominent differential diagnosis of both nodular KS and PG was bacillary angiomatosis ${ }^{11,12}$. It is a disorder characterized by neovascular proliferation in the skin or the internal organs caused by Bartonella henselae or Bartonella quintana infection. Originally, bacillary angiomatosis was described in human immunodeficiency virus (HIV) patients but is known to occur in other non-HIV immunocompromised states as well as in immunocompetent individuals ${ }^{11}$. Moreover, the solitary or multiple angiomatous, friable papules, and nodules are the most common clinical findings. The appearance of the cutaneous lesions may be indistinguishable from that of KS and PG ${ }^{11,12}$. Sławińska et al. ${ }^{13}$ recently reported the dermatoscopical characteristics of nodules in bacillary angiomatosis and found branched linear vessels, whitepinkish structureless areas, and brownish peripheral structureless area. Although some characteristics are similar to PG, histopathology confirms the diagnosis of bacillary angiomatosis by revealing bacilli on sections using Warthin-Starry method or other silver stains ${ }^{12}$.

PG and nodular-type KS can have similar clinical, histopathological, and dermatoscopical characteristics that are similar to the case presented. To achieve the correct diagnosis in suspicious cases, all non-pigmented, pink-red single lesions should be excised and histopathologically examined. When components of both $\mathrm{KS}$ and $\mathrm{PG}$ are present in the same lesion, HHV-8 immunostaining is recommended. To the best of our knowledge, this is the first case of PG-like nodular-type KS that exhibits dermatoscopical characteristics of PG in addition to clinical and histopathological characteristics.

\section{Ethics}

Informed Consent: Informed consent was obtained.

Peer-review: Externally peer-reviewed.

\section{Authorship Contributions}

Surgical and Medical Practices: H.G.D., E.B., Concept: H.G.D., E.B., B.T., Design: H.G.D., Data Collection or Processing: H.G.D., Analysis or Interpretation: E.B., B.T., Literature Search: H.G.D., E.B., Writing: H.G.D. Conflict of Interest: No conflict of interest was declared by the authors.

Financial Disclosure: The authors declared that this study received no financial support.

\section{References}

1. Hu SC, Ke CL, Lee CH, Wu CS, Chen GS, Cheng ST: Dermoscopy of Kaposi's sarcoma: areas exhibiting the multicoloured 'rainbow pattern'. J Eur Acad Dermatol Venereol 2009;23:1128-32.

2. Ertürk Yllmaz T, Akay BN, Okcu Heper A: Dermoscopic findings of Kaposi sarcoma and dermatopathological correlations. Australas J Dermatol 2020;61:e46-53.

3. McClain CM, Haws AL, Galfione SK, Rapini RP, Hafeez Diwan: Pyogenic granuloma-like Kaposi's sarcoma. J Cutan Pathol 2016;43:549-51.

4. Scott PL, Motaparthi K, Krishnan B, Hsu S: Pyogenic granuloma-like Kaposi sarcoma: a diagnostic pitfall. Dermatol Online J 2012;18:4.

5. Cabibi D, Cacciatore M, Viviano E, Guarnotta C, Aragona F: 'Pyogenic granuloma-like Kaposi's sarcoma' on the hands: immunohistochemistry and human herpesvirus-8 detection. J Eur Acad Dermatol Venereol 2009;23:5879.

6. Korekawa A, Kaneko T, Nakano H, Sawamura D: Pyogenic granuloma-like Kaposi's sarcoma on the first toe. J Dermatol 2018;45:e177-8.

7. Lee MK, Ku SH, Cho EB, Park EJ, Kim KH, Kim KJ: Unusual case of pyogenic granuloma-like Kaposi's sarcoma on the sole. J Dermatol 2015;42:425-6.

8. Elmas ÖF, Akdeniz N, Acar EM, Kilitçi A: Pyogenic granuloma and nodular Kaposi's sarcoma: dermoscopic clues for the differential diagnosis. Turk $J$ Med Sci 2019;49:1471-8.

9. Zaballos P, Carulla M, Ozdemir F, et al: Dermoscopy of pyogenic granuloma: a morphological study. Br J Dermatol 2010;163:1229-37.

10. Şahin MT: Vasküler lezyonlar. In: Özdemir F, (editor). Dermoskopi Atlası, 1th ed. Ankara: Dünya Tıp Kitabevi; 2017;231-7.

11. Akram SM, Anwar MY, Thandra KC, Rawla P: Bacillary angiomatosis. In: StatPearls [Internet]. Treasure Island (FL): StatPearls Publishing; 2021.

12. Aydoğan I, Parlak AH, Alper M, Aksoy KA: Bacillary angiomatosis in an HIV seronegative patient. Turk Arch Dermatol Venereol 2004;38:71-4.

13. Sławińska M, Sokołowska-Wojdyło M, Hlebowicz M, Biernat W, Nowicki RJ, Sobjanek M: Numerous, disseminated, purplish skin nodules in a patient with chronic lymphocytic leukemia. Pol Arch Intern Med 2021;131:81-2. 